\title{
Sources of Uncertainty in Timber Supply Projections ${ }^{1}$
}

\author{
by
}

\author{
P.L. Marshall ${ }^{2}$
}

\begin{abstract}
Uncertainty surrounding timber supply projections can arise from many sources. This paper examines some of the sources connected with the modelling of timber supply and the environment within which timber supply projections are applied. No attempt is made to quantify or rank these sources. The intent is to stimulate awareness of the extent of uncertainty in timber supply projections and promote discussion that could lead to improved management of timber resources.
\end{abstract}

Key words: Uncertainty, Timber Supply Modelling, Timber Supply Projections.

\section{Résumé}

L'incertitude entourant les projections d'approvisionnement en matière ligneuse peut surgir de plusieurs causes. Cet exposé explore quelques unes des causes reliées à la modélisation des approvisionnement en matière ligneuse et de l'environnement entourant chacune de ces zones d'approvisionnement où les projections sont appliquées. Aucune tentative n'est faite pour quantifier ou classer par ordre de grandeur ces causes. Le but suivi est de stimuler l'intérêt pour cerner ces incertitudes dans les projections d'approvisionnement en matière ligneuse et provoquer des discussions qui pourraient menées à un aménagement amélioré des ressources ligneuses.

Mots clés: Incertitude, Modélisation d'approvisionnement en matière ligneuse, projection d'approvisionnement en matière ligneuse.

\section{Introduction}

Forestry has been defined as "the study and practice of managing forest land and associated resources" (Duerr 1974a). The term "management" implies making decisions (Duerr et al. 1968). Decisions require choice of an alternative based on perceptions of potential future returns (outcomes) which will be shaped by future events. Decisions are said to be made under uncertainty if there is more than one potential outcome for each alternative and the probability of each potential outcome is not known (Knight 1921). Alternatives with a greater range of potential outcomes are more uncertain than alternatives with a smaller range. Acquiring information concerning events that affect outcomes is the key to reducing uncertainty (Duerr 1974b).

Uncertainty can result in "sub-optimal" decisions that differ from those that would be made if the future were known. In other words, uncertainty can cause outcomes other than the most preferred. Any difference between the actual and the most preferred outcome represents a loss to the decision maker.

A rational decision requires ranking of the potential outcomes and choice of an alternative that appears to

'Partial funding for this paper was provided by the Forest Economics and Policy Analysis project at the University of British Columbia.

2Dept. For. Res. Mgmt., Fac. of For., Univ. of British Columbia, Vancouver, B.C. V6T IW5 optimize return. For the forest manager to make rational choices regarding management of the forest, the uncertainty involved must be recognized and quantified, if at all possible.

Models of timber supply often are used to project the impact of possible havesting levels and to develop broad strategies for managing timber. Together with environmental, economic, physical, institutional and socio-political considerations, projections of timber supply are employed to aid decisions on how the timber resource is to be managed.

This paper explicitly addresses sources of uncertainty that affect projections of timber supply. Uncertainty that affects timber supply projections arises from factors internal to the "environment" explicitly examined in models of timber supply as well as from factors external to this environment. The internal factors govern whether the timber resource will respond as predicted given that the harvesting and management activities assumed are implemented as designed. The external factors govern whether harvest levels and associated management activities are implemented as designed and how long they remain appropriate. Each of these groups of factors will be discussed separately.

\section{Sources of Uncertainty Internal to Timber Supply Models}

Timber supply models use existing inventory data, and assume particular management strategies and harvesting rules, to track the growing stock base and estimate the 
quantity harvested over time. Timber supply projections are uncertain because of simplifications required for modelling, inaccuracies in the inventory data base, and possible errors in projecting that data base through time.

\section{Model Formulation}

Timber supply models are commonly solved by either mathematical programming or simulation techniques. Models designed for solution by mathematical programming techniques must conform to particular mathematical structures. This can greatly restrict the flexibility of the model to reflect specific relationships. For example, models that are to be solved using linear programming must have a linear mathematical structure. Simulation-based models require no mathematical restrictions and provide responses to a number of "what if" questions.

Any timber supply model must compromise in the areas of flexibility, treatment of spatial components and resolution to keep the model to a workable size. Flexibility is sacrificed by imposing rigid rules to control the number and type of management activities considered, harvesting rules, et cetera. Often, spatial distribution of timber types is ignored (with the possible exception of access restrictions), and the assumption is made that each timber type exists as one contiguous unit. Problem size restrictions also require that many distinct stands be aggregated into relatively few timber classes. The greater the aggregation, the poorer the resolution of the model, and the larger the amount of information in the initial data base that is lost.

The magnitude of uncertainty caused by using a particular model will vary with the specific circumstances and the model considered. User's manuals for most timber supply models discuss model limitations and assumptions. Models that have been widely applied and/or which follow standardized techniques have more information available. For example, Johnson and Scheurman (1977) provided information on linear programming approaches in general. Model limitations of Timber RAM were discussed by Navon (1971) and Chappelle et al. (1976). This information is useful in deciding whether the model is appropriate for the circumstances and the existing data base, and whether it is feasible to modify the model or certain coefficients.

It is possible to test the impact of imprecise model formulation on projection of timber supply through sensitivity analyses. However, as long as the user remains cognizant of the model assumptions and the characteristics of the specific data base to which the model will be applied, it will usually be possible to minimize any contribution of model form to the overall uncertainty.

\section{Inventory Requirements}

Estimates of net volume per ha available from different age and timber classes, and the areas associated with these, are provided by forest inventories. Uncertainty regarding these estimates can theoretically be removed by gathering a complete information set. Practically, this is not possible or even desirable because of the vast size of the information base required, the data aggregation that will subsequently occur and the uncertainty associated with future forest composition.

Various reductions may be made to the initial inventory information to reflect non-commercial timber types, poor sites, and local utilization standards. The end result can be an estimate of net yield that is quite fuzzy. Additional information can be gathered to reduce this uncertainty. Just because this information can be gathered with relative ease however, is not sufficient justification for doing so. Information that relfects the dynamic nature of the forest can be more valuable in reducing uncertainty surrounding projections of timber supply than information that is static or limited in application.

The key means of minimizing the uncertainty contributed by inventory data is to maintain compatibility between the information provided by the inventory and the information needs of the supply model. Timber supply analyses, because of the tremendous data aggregation required, need sound information upon which to base the aggregation. The final timber classes will be most applicable if the descriptive variables chosen to describe the original land units are the most important to the model structure as evidenced by its state variables (Williams and Yamada 1976). Compatibility also extends to the timing of the information. The more recent the inventory, the clearer the picture supplied by a timber supply analysis.

\section{Yield Projections}

Projection of yield requires assumptions concerning the future so uncertainty can never be totally removed from these projections. It can be reduced, however. Research into the biological and physical processes of the forest can increase understanding of forest dynamics. Historical responses can be analyzed in the light of present understanding and provide insight into potential future conditions.

The quantity of timber that will be available at any time in the future is dependent upon two factors: (1) the amount of economically accessible land present in merchantable timber classes at that time; and (2) the yield of merchantable timber from each of these classes.

Predictions of the future economically accessible, merchantable land base can be made from an understanding of present technological conditions, expected demands on the forest land base for uses that are incompatible with timber harvesting, present growing stock composition and distribution, and changes to this through harvesting and catastrophic mortality. Technology should improve with time and allow profitable harvesting of land now classified as noncommercial or inaccessible. An increase in the real price of timber products or the development of markets for products based on species or sizes of timber currently considered noncommercial could have a similar effect. Anticipation of such developments should be an important component of forest planning, but would be difficult to incorporate into existing timber supply models.

Timber supply models, by their very nature, reflect changes to the growing stock distribution anticipated from harvesting. Changes to the growing stock base through catastrophic mortality have seldom been directly incorporated, and are often treated by applying deductions to the net yield from a given timber type. Techniques now exist for direct incorporation of catastrophic mortality in particular timber supply model formulations and results can be significantly different from those produced by the traditional approach (Reed and Errico 1985).

Estimation of yield from different timber classes is centered on an understanding of forest dynamics. Yield changes with time as a result of complex interactions between 
the biotic and abiotic components of the forest. Future yield is a function of present stand conditions (both biotic and abiotic), climatic influences and the non-catastrophic impact of damaging agents (pathogens, insect pests, wind, and so on). The physical properties associated with a forest area provide raw materials for growth and limit production potential. Management activities influence production either through altering the composition of the stand or by altering the site.

Yield projections usually attempt to predict "average" conditions for a particular timber class at some time in the future. Future stand conditions become less certain the farther into the future the projection is made. This uncertainly is further confounded by incomplete understanding of the effects of different management practices on stand dynamics. Considerable effort has been directed towards establishing managed stand yield projection systems in recent years. (See, for example, Curtis et al. 1982, Mitchell and Cameron 1985, Wykoff et al. 1982, and Arney 1985.) However, much more work remains to be done before a system is developed that can predict consistently the response of a stand to specific management activities.

With more intensive management, future timber yields should improve in quality and/or quantity. The questions of how much they will improve, and how this should affect present levels of harvesting remain to be answered.

\section{Sources of Uncertainty External to Timber Supply Models}

Timber supply models generally address only the portion of the forest that is targeted for timber production. A significant part of the uncertainty surrounding timber supply projections relates to how well the forest area assumed in the model resembles that which will be available and whether the management activities assumed are implemented. The former was addressed in the previous section from a technical aspect, but there are social considerations as well. This section will examine some of the social aspects that contribute to the uncertainty of timber supply projections.

\section{The Changing Nature of the Problem}

An important forest management problem is the gap between the actual state and the desired state of the forest system (Marshall 1986). The actual state is in constant flux as a result of natural processes and interventions by man. The desired state changes as public demands for forest resources vary in accordance with technological innovations, the state of the economy, and other factors quite external to the forest system itself. Since many changes to the forest system take a long time to manifest themselves following some initial action, there is no guarantee that the resultant (actual) state of the system will be on a trajectory toward the future desired state. This is true even if all proposed changes to the present state occur as predicted.

Historical trends in consumption of forest products will provide some insight into possible directions in the near future. Much uncertainty remains about conditions in the distant future because it is highly dependent upon technological innovations and many other factors impossible to quantify accurately.

\section{Improper Specification of Returns}

The interpretation and weighting of various returns from a forest provide a basis for allocating land to various uses. Imprecise specification of the individual contribution of resource uses to some measure of overall return can lead to allocating land to various uses (including timber) that are far from optimal.

This difficulty is particularly important on public forest land. It is the responsibility of the forest management agency, and ultimately the political hierarchy to which the agency is responsible, to decide how returns from components of the forest system will be weighted. Certain of the returns, aesthetics and recreational values for example, are difficult to quantify in monetary terms. This makes tradeoffs among mixtures of forest resource uses difficult to justify objectively.

Planning processes for public lands normally provide opportunity for public input. Quite often the effects of a plan are monitored during and after implementation and opportunity is provided for public feedback. Unfortunately, public input tends to come mainly from special interest groups with polarized viewpoints and the onerous task of trying to find some acceptable compromise still remains. Frequently the public is not well informed and lacks the necessary training to understand the biological and economic processes of the forest.

There will always be difficulty measuring well-being and assessing how forest resources contribute to it. Social attitudes and priorities change over time and the contributions of various resources will change as well. Further complications come from geographical variations in both perceptions of, and requirements from, the forest.

\section{Political Constraints}

The fact that management decisions for public forest land are ultimately made in a political forum can restrict selection of management strategies, harvest levels and allocation of land to various resource uses. The extent of these restrictions will probably change with the political climate, but they can have a profound impact on the management activities that are implemented and the frequency and direction of future revisions.

Cortner and Schweitzer (1980) captured the essence of political limitations on selection of potential management alternatives for public resource planning in the United States. Although their discussion is specific to the American situation, they stated that much of it could be generalized if certain conditions hold.

The argument presented can be summarized as follows. The survival of a bureaucratic agency is dependent upon its ability to attract and maintain outside political support. Since planning by a public agency is taken as a stance of the bureaucracy as a whole, most assumptions about future conditions tend to be positive and growth oriented since other assumptions can lead to political confrontations. Alternatives that could lead to significant changes in resource allocations, even in the distant future, could be avoided for similar reasons.

A long-term perspective is necessary to manage forest resources properly. The political process encourages decision makers to focus on the short-term and favor immediate payoffs and delayed expenditures. This attitude could be detrimental in the long run.

\section{Policy Specifications}

Policy implicitly or explicitly dictates the connection of timber harvesting to other forest uses through its impact on the 
allocation of forest land to various uses. These uses may be complementary or in direct competition with timber given the limitations of the land base. Policy also determines the structure of the timber supply model or models employed through the specification of a management philosophy. The extent to which the philosophy embodied in the timber supply model structure is actually followed in setting harvesting levels and implementing a compatible management strategy will determine the usefulness of the timber supply modelling procedure.

\section{Conclusion}

Uncertainty is present when potential outcomes of any decision are affected by factors that the decision maker can neither predict nor control. This paper has examined some of the sources of uncertainty, internal and external to the modelling process, affecting timber supply projections. Recognition of uncertainty in timber management is an important step towards improving management. It is only through recognition and subsequent discussions that the development of a common framework for quantifying uncertainty in forest management decisions can be achieved. This is a necessary step for sound assessments of the risks involved in making timber management investments.

\section{References}

Arney, J.D. 1985. A modeling strategy for the growth projection of managed stands. Can. J. For. Res. 15: 511-518.

Chappelle, D.E., M. Mang and R.C. Riley. 1976. Evaluation of Timber RAM as a forest planning model. J. For. 66: 760-763.

Cortner, H.J. and D.L. Schweitzer. 1980. Public forest planning and reality: industrial problems and limitations. In Symposium on Forest Management Planning: Present Practice and Future Directions. Aug. 1980. Virginia Poly. Inst. and State Univ.,
Blacksburg, Va. Sch. of For. and Wildl. Resour. Pub. FWS-1-81. p. 11-26.

Curtis, R.O., G.W. Clendenen, D.L. Reukema and D.J. DeMars. 1982. Yield tables for managed stands of coast Douglas-fir. USDA For. Serv. Gen. Tech. Rep. PNW-135. 182 pp.

Duerr, W.A. 1982a. Forestry as a system. In Forest Resource Management: Decision-making, Principles and Cases. W.A. Duerr, D.E. Teeguarden, S. Guttenberg and N.B. Christiansen (Editors). O.S.U. Bookstores Inc., Corvallis, Oregon. p. 1.1-1.6.

Duerr, W.A. 1982b. Models in non-deliberated decision-making. In Forst Resource Management: Decision-making, Principles and Cases. W.A. Duerr, D.E. Teeguarden, S. Guttenberg and N.B. Christiansen (Editors). O.S.U. Bookstores Inc., Corvallis, Oregon. p. 14-1-14.30

Duerr, W.A., D.E. Teeguarden and S. Guttenberg. 1968. Decision making in forest resource management. J. For. 66: 760-763.

Johnson, K.N. and H.L. Scheurman. 1977. Techniques for prescribing optimal timber harvest and investment under different objectives - discussion and synthesis. For. Sci. Monograph $18.31 \mathrm{pp}$.

Knight, F.H. 1921. Risk, uncertainty and profit. Houghton Miffen Co., Boston.

Marshall, P.L. 1986. A decision context for timber supply modelling. For. Chron. 62: 533-536

Mitchell, K.J. and I.R. Cameron. 1985. Managed stand yield tables for coastal Douglas-fir: initial density and precommercial thinning. BC Min. For. Land Manag. Rep. No. 31. 69 pp.

Navon, D.I. 1971. Timber RAM - a long-range planning method for commercial timberlands under multiple-use management. USDA For. Serv. Res. Pap. PSW-70. 22 pp.

Reed, W.J. and D. Errico. 1985. Optimal harvest scheduling at the forest level in the presence of risk of fire. Forest Economics and Policy Analysis Project Inform. Rep. 85-3. 47 pp.

Williams, D.H. and M.M. Yamada. 1976. A clustering technique for land management models. Can. J. For. Res. 6: 532-538.

Wykoff, W.R., N.L. Crookston and A.R. Stage. 1982. User's guide to the stand prognosis model. USDA For. Serv. Gen. Tech. Rep. INT-133.

\section{Retired Members}

This note is to remind retired members and Section Councils about the provisions of By Law 4.4 which allows individuals who have been Institute members for 15 or more years and who retire "with a substantial reduction in income" to apply for retired status. If approved, retired status members are not required to pay any dues, but retain all rights and benefits except receipt of The Forestry Chronicle. The Chronicle is available to retired members on payment of the regular subscription rate for individuals (\$29.00 for 1987).

The proper procedure for those interested in this provision is to apply to your Section Council. Councils will deal with these applications and notify National Office of the decision so that records can be adjusted.

\section{R.J. Bourchier}

Executive Director 